/ О.А. Комаренко // Вісник економіки і промисловості. - 2017 - Вып. 59. - С. 290300.

14. Размещение производительных сил и региональная экономика: Учеб. пособие / Е. П. Кочан, Т.Е. Царик, Д.В. Ткач и др.; Под ред. проф. Е. П. Початка. К.: Юридическая книга, 2005. -704 с.

15. В 2017 году Украина сократила добычу угля / [Электронный ресурс]. Режим доступа: http://minprom.ua/news/240088.html

16. Итоги работы промышленности Украины за 9 месяцев 2017 года - кризис продолжается // [Электронный ресурс]. Режим доступа: https:// istina.net.ua/ informatsiia/politika/426-itogi-rabotypromyshlennosti-ukrainy-za-9-mesyatsev2017-goda-krizis-prodolzhaetsya

17. Проект Украина: что прорастет. Десять самых привлекательных отраслей украинской экономики для инвестиций // [Электронный ресурс]. - Режим доступа: http://www.liga.net/projects/ukraine_investme $\mathrm{nt} /$

18. Дикань В.Л. Украина в глобальной микросистеме: особенности и последствия государственной экономической политики / В.Л. Дикань, A.B. Обруч // Вісник економіки i промисловості. - 2017 - Вып. 59. - С. 1119.

19. Сисенко Н. Транзитные возможности Украины: потенциала нет? / Н. Сисенко // [Электронный ресурс]. Режим доступа: https://ubr.ua/ finances/macroeconomics-ukraine/tranzitnyevozmojnosti-ukrainy-potenciala-net-47822

20. Перебейнос О.М. Демографічна безпека та загрози демографічного розвитку: державно-управлінський аспект / О.М. Перебейнос.- [Електронний ресурс]. Режим доступу: http://www.kbuapa.kharkov.ua/ebook/db/2011-1/doc/7/03.pdf

21. Моравецкий: Польша приняла десятки, может, сотни тысяч беженцев из Украины / М. Моравецкий // [Электронный ресурс]. - Режим доступа:

http://gordonua.com/news/worldnews/ moraveckiy-polsha-prinyala-desyatki-mozhetsotni-tysyach-bezhencev-iz-ukrainy224884.html

22. Необратимый процесс начат: к чему приведет демографический кризис. [Электронный ресурс]. - Режим доступа: https://mhub.top/2017/12/25/ neobratimyjprotsess-nachat-k-chemu-privedyotdemograficheskij-krizis-na-ukraine/

\title{
АКТУАЛЬНІСТЬ РОЗВ'ЯЗАННЯ В УКРАЇНІ ПИТАННЯ НЕДОПУЩЕННЯ ВИКОРИСТАННЯ ТУРИСТИЧНИХ КАНАЛІВ ДЛЯ НЕЛЕГАЛЬНОЇ МІГРАЦІЇ ТА ТОРГІВЛІ ЛЮДЬМИ В УМОВАХ СВРОІНТЕГРАЦIÏ
}

\author{
Козлова А. О., к.е.н., ст. викладач (ХНУМГ імені О.М. Бекетова)
}

В статті досліджено динаміку туристичних потоків в Украӥні та зроблено висновок щзоо їх зростання в останні роки, у тому числі через політику євроінтеграчіï. Виявлено, щзо розвиток туризму в Україні супроводжується потиренням нелегальної міграції. Розкрито чинники, щз сприяють використанню нелегальної міграції через туристичні канали України. Визначено шляхи розв'язання 
питань нелегальної міграчії через туристичні канали, обтрунтовано необхідність системного комплексного підходу з боку як державних інституцій, так $i$ туристичного сектору щзодо недопущення використання туристичних легальних каналів для нелегальної міграчії та торгівлі людьми.

Ключові слова: туризм, міграція, нелегальна міграція, туристичний канал, злочинні угрупування в сфері нелегальної міграції, правові механізми забезпечення міграційної політики.

\title{
АКТУАЛЬНОСТЬ РЕШЕНИЯ В УКРАИНЕ ВОПРОСА НЕДОПУЩЕНИЯ ИСПОЛЬЗОВАНИЯ ТУРИСТИЧЕСКИХ КАНАЛОВ ДЛЯ НЕЛЕГАЛЬНОЙ МИГРАЦИИ И ТОРГОВЛИ ЛЮДЬМИ В УСЛОВИЯХ ЕВРОИНТЕГРАЦИИ
}

\section{Козлова А. А., к.э.н., ст. преподаватель (ХНУГХ имени А.Н. Бекетова)}

В статье исследована динамика туристических потоков в Украине и сделан вывод о их росте в последние годы, в том числе из-за политики евроинтеграции. Выявлено, что развитие туризма в Украине сопровождается распространением нелегальной миграчии. Раскрыто факторы, способствующие использованию нелегальной миграчии через туристические каналь Украины. Определены пути решения вопросов нелегальной миграчии через туристические каналь, обоснована необходимость системного комплексного подхода со стороны как государственных институтов, так и туристического сектора по недопущению использования туристических легальных каналов для нелегальной миграции и торговли людьми.

Ключевые слова: туризм, миграция, нелегальная миграция, туристический канал, преступные группировки в сфере нелегальной миграции, правовые механизмы обеспечения миграционной политики.

\section{ACTUALITY OF THE QUESTION CONCERNING MISTAKES OF USE TOURISTIC CHANNELS FOR ILLEGAL MIGRATION AND TRAFFICKING IN HUMAN BEINGS IN UKRAINE IN THE CONDITIONS OF EU INTEGRATION}

\author{
Kozlova A. O., PhD in Economic. \\ (O.M.Beketov National University of Urban Economy)
}

The article investigates the dynamics of tourist flows in Ukraine and concludes about their growth in recent years, including through the policy of European integration. It is revealed that the development of tourism in Ukraine is accompanied by the spread of illegal migration. The factors that promote the use of illegal migration through the tourist channels of Ukraine are revealed. The main factors of the existence of illegal migration in our country include the exacerbation of the socio-political situation in a number of countries in Asia and the Middle East, primarily in Afghanistan and Syria, as well as the complex military-political situation in eastern Ukraine. The ways of solving the issues of illegal migration through tourist channels have been identified. ,the necessity of the system complex approach by both state institutions and the tourism sector was substantiated in order to prevent the use of tourist legal channels for illegal migrant, and trafficking.

Вісник економіки транспорту і промисловості № 61,2018 
Keywords: tourism, migration, illegal migration, tourist channel, criminal groups in the field of illegal migration, legal mechanisms of ensuring migration policy.

Постановка проблеми та іiі зв'язки 3 науковими чи практичними завданнями. Завдяки своєму географічному положенню Україна знаходиться на перехресті шляхів між «Сходом і Заходом», iï територією проходять міжнародні транспортні коридори, здійснюється рух робочої сили, туристів, товарів. Таке геополітичне положення значною мірою упродовж багатьох століть детермінувало історичні, культурні, духовні й політичні особливості розвитку нашої держави.

Наш час характеризується збільшенням масштабів міграційних процесів у світі, розширенням та розвитком зв'язків та інтеграції між країнами. Міграція як економічна, правова категорія і як соціально-економічне явище відома 3 стародавніх часів. Поштовхом для масового переміщення населення стали, перш за все, великі географічні відкриття, а згодом - pух капіталу i розвиток капіталізму. Разом з цим, з боку держави запроваджувалися заходи щодо захисту свого економічного та трудового потенціалу шляхом визначення кордонів, запровадження політики стримування потоків мігрантів, які на початковому етапі розвитку багатьох нині розвинутих країн, зіграли позитивну роль.

Однак, в сучасних умовах активізації процесів євроїнтеграції географічне положення України почали активно використовувати 3 метою нелегальної міграції, транспортування мігрантів та торгівлі людьми, що i підтверджує актуальність розв'язання питань недопущення використання туристичних каналів для нелегальної міграції.

Аналіз останніх досліджень i публікацій. Організаційно-управлінські та правові аспекти протидії нелегальній міграції розкривають в своїх праці такі вітчизняні вчені як О. Боков [1], I. Василенко [2], В. Коваленко, В. Кривенко [3], I. Кресіна, О. Стойко [4], А. Мозоль [5], В. Левковський [6], В. Олефір [7], Ю. Римаренко [8] та інші.

Виділення невирішених частин загальної проблеми. В той же час, вивченню проблем використання легальних міграційних можливостей для організації нелегальних каналів міграції та торгівлі людьми, в тому числі туристичних каналів, приділяється недостатньо уваги. Наукові дослідження за вказаною тематикою є досить актуальними саме в період євроінтеграційних процесів в Україні.

Метою статті $є$ дослідження питань недопущення використання легальних міграційних можливостей для організації нелегальних каналів міграції та торгівлі людьми, насамперед туристичних каналів, надання пропозицій щодо пріоритетних напрямків вирішення вказаної проблеми.

Виклад основного матеріалу. Нелегальна міграція у колишньому СРСР була майже відсутня. Тому, будь-яких програм боротьби з нею не існувало. Після здобуття Україною незалежності та надання iї громадянам можливостей вільно пересуватися країнами світу міграційні процеси 3 кожним роком стрімко збільшувалися. 3 початку нового століття та зростання добробуту українців також стрімкого розвитку зазнала туристична галузь i як наслідок почали зростати туристичні потоки. Додатково цим процесам сприяли лібералізація режиму перебування в нашій країні для іноземних громадян, привабливе географічне становище та введення 32017 року спрощеного режиму перетину державного кордону з України до країн ЄС (табл. 1). 
Таблиияя 1

Туристичні потоки, осіб [9]

\begin{tabular}{|c|c|c|c|c|c|c|}
\hline & \multirow{2}{*}{$\begin{array}{c}\text { Кількість } \\
\text { громадян } \\
\text { України, } \\
\text { які } \\
\text { виїжджали } \\
\text { за } \\
\text { кордон - } \\
\text { усього }\end{array}$} & \multirow[b]{2}{*}{$\begin{array}{c}\text { Кількість } \\
\text { іноземних } \\
\text { громадян, } \\
\text { які } \\
\text { відвідали } \\
\text { Україну - } \\
\text { усього }^{2}\end{array}$} & \multirow{2}{*}{$\begin{array}{c}\text { Кількість } \\
\text { туристів, } \\
\text { обслугованих } \\
\text { суб'єктами } \\
\text { туристичної } \\
\text { діяльності } \\
\text { України - } \\
\text { усього }^{3}\end{array}$} & \multicolumn{3}{|c|}{ У тому числі } \\
\hline & & & & $\begin{array}{l}\text { іноземні } \\
\text { туристи }\end{array}$ & $\begin{array}{c}\text { туристи- } \\
\text { громадяни } \\
\text { України, } \\
\text { які } \\
\text { виїжджали } \\
\text { за кордон }\end{array}$ & $\begin{array}{c}\text { внутрішні } \\
\text { туристи }\end{array}$ \\
\hline 2000 & 13422320 & 6430940 & 2013998 & 377871 & 285353 & 1350774 \\
\hline 2001 & 14849033 & 9174166 & 2175090 & 416186 & 271281 & 1487623 \\
\hline 2002 & 14729444 & 10516665 & 2265317 & 4417729 & 302632 & 1544956 \\
\hline 2003 & 14794932 & 12513883 & 2856983 & 590641 & 344332 & 1922010 \\
\hline 2004 & 15487571 & 15629213 & 1890370 & 4436311 & 4441798 & 1012261 \\
\hline 2005 & 16453704 & 17630760 & 1825649 & 326389 & 5666942 & 932318 \\
\hline 2006 & 16875256 & 18935775 & 2206498 & 299125 & 868228 & 1039145 \\
\hline 2007 & 17334653 & 23122157 & 2863820 & 372455 & 336049 & 2155316 \\
\hline 2008 & 15498567 & 25449078 & 3041655 & 372752 & 1282023 & 1386880 \\
\hline 2009 & 15333949 & 20798342 & 2290097 & 282287 & 913640 & 1094170 \\
\hline 2010 & 17180034 & 21203327 & 2280757 & 335835 & 1295623 & 649299 \\
\hline 2011 & 19773143 & 21415296 & 2199977 & 234271 & 1250068 & 7 \\
\hline 2012 & 21432836 & 23012823 & 3000696 & 270064 & 1956662 & $7 \overline{773970}$ \\
\hline 2013 & 23761287 & 24671227 & 3454316 & 232311 & 2519390 & 702615 \\
\hline $2014^{1}$ & 22437671 & 12711507 & 2425089 & 17070 & 2085273 & 322746 \\
\hline $2015^{1}$ & 23141646 & 12428286 & 2019576 & 15159 & 1647390 & 357027 \\
\hline $2016^{1}$ & 24668233 & 13333096 & 2549606 & 35071 & 2060974 & 4453561 \\
\hline
\end{tabular}

${ }^{1}$ Без урахування тимчасово окупованої території Автономної Республіки Крим, м.Севастополя та частини зони проведення антитерористичної операції

2 Включно з одноденними відвідувачами (за даними Адміністрації Держприкордонслужби України)

3 2000-2010 за даними Міністерства інфраструктури України, починаючи 32011 року за даними Держстату

Вищевказані переваги почали фахівці Державної міграційної та активно використовуватися i 3 метою Державної прикордонної служб на нелегальної міграції, транспортування сьогодні виділяють загострення соціальномігрантів та торгівлі людьми за межі політичної ситуації у низці країн Азії та України. Як наслідок Україна була Близького Сходу, насамперед в вимушена створити та запровадити Афганістані та Сирії, а також складну систему протидії нелегальній міграції та воєнно-політичну обстановку на сході торгівлею людьми, ратифікувати України. До другої групи чинників міжнародні акти щодо протидії цим належить високий міграційний потенціал ганебним явищам, особливо в період нашої країни за рахунок іноземців, які активізації процесів долучення до раніше легально прибули в державу, 3 європейської спільноти.

Серед головних факторів існування незаконної міграції в нашій державі чого випливає наявність розгалуженої пособницької бази серед представників іноземних діаспор і мешканців 
прикордоння. До речі, необхідно пам'ятати, що цей кримінальний «бізнес» приносить надприбутки. Додає проблем i доволі ліберальне законодавство та недосконала система міграційного контролю, що сприяє легальному в’їзду незаконних мігрантів в Україну, а також дає можливість зловживати тимчасовою легалізацією на території держави та процедурою отримання статусу біженця.

Активне запровадження системи обліку та обміну інформацією про особу між різними країнами, впровадження хоча i прозорих, але сучасних i дієвих механізмів легального перетинання кордону, а саме: обмін біометричними даними, інші засоби протидії злочинності та тероризму, ускладнило діяльність злочинних угрупувань, що спеціалізуються на нелегальній міграції та торгівлі людьми. Це спонукало злочинців шукати і використовувати інші, в тому числі легальні та напівлегальні можливості щодо перетинання кордону та доставки мігрантів в інші країни. Перелічимо основні шаблони, які використовують нелегальні мігранти при використання легальних можливостей:

по-перше, використовують дійсні паспортні документи та справжні українські візи, але видані на запрошення підставних приватних осіб, підроблені запрошення навчальних закладів, туристичні ваучери, неіснуючих приватних і державних підприємств; по-друге, отримують чужі та підроблені національні паспорти, документи громадян європейських країн, а також підроблені посвідки на постійне або тимчасове проживання в Україні, підроблені (недійсні) відмітки Державної прикордонної служби.

В той же час при використанні таких способів перетинання кордону існує значна вірогідність затримання правоохоронцями, як раз з причин які наведені вище. В результаті, у правопорушників, які використовують вищенаведені шаблони виникла потреба більш гарантованого уникнення від переслідування правоохоронцями, а також більш масштабного використання легальних каналів для своєї протиправної діяльності.

Одним із таких легальних каналів, який активно став використовуватися організаторами нелегальної міграції ще 3 90-х років минулого століття, $\epsilon$ туристичний канал в'їзду-виїзду.

Туристична міграція перш за все характеризується задоволенням певних інтересів людей, іноді 3 можливим відпочинком, обміном туристичними групами тощо. Це, зазвичай, короткострокове переміщення окремих верств населення. В сучасних умовах туризм перетворився на потужну індустрію, а глобалізація, кооперація та лібералізація процесу переміщення людей лише сприяє цьому. Індустрія туризму впродовж останніх десятиліть стала однією 3 найважливіших сфер економіки, забезпечуючи десяту частину всього світового валового продукту. Уряди більшості держав світу, насамперед економічно залежних від туристичних потоків, активно заохочують туристів до своїх країн, сприяють та спрощують процеси потрапляння до країни іноземців, які слідують через туристичні канали.

$$
\text { Учасниками відносин, що }
$$

виникають при здійсненні туристичної діяльності, є юридичні та фізичні особи, які створюють туристичний продукт, надають туристичні послуги (перевезення, тимчасове розміщення, харчування, екскурсійне, курортне, спортивне, розважальне та інше обслуговування) чи здійснюють посередницьку діяльність із надання характерних та супутніх послуг, а також громадяни України, іноземці та особи без громадянства (туристи, екскурсанти, відвідувачі та інші), в інтересах яких здійснюється туристична діяльність [10].

$$
\text { В результаті легальними }
$$

можливостями, які надаються саме туристичними установами (сприяння 
щодо оформлення віз, закордонних паспортів, квитків і т.ін.), а також зменшення уваги правоохоронних, митних, прикордонних структур до організованих туристів на відміну від інших категорій, наприклад трудових мігрантів, скористалися злочинні угрупування, які спеціалізуються на нелегальній міграції та торгівлі людьми.

Слід зазначити, що непоодинокими $\epsilon$ випадки створення організованих злочинних угрупувань, в тому числі транснаціонального характеру, до складу яких входять не тільки злочинці, що спеціалізуються на нелегальній міграції та торгівлі людьми, а й працівники туристичної галузі. У них налагоджені робочі стосунки 3 представниками міграційних та прикордонних служб, митниці, перевізниками, туристичними операторами, а це в свою чергу $\epsilon$ привабливим для організаторів нелегального перетинання кордону. Саме через співробітників туристичних установ нерідко, наприклад, здійснюється оформлення «фіктивних» запрошень, в тому числі групових, на міжнародні конференції, симпозіуми, спортивні змагання, концерти, інші масові заходи. Формування «достовірної або чистої» візової чи кредитної історії, підтвердження трудової діяльності, навчання, реєстрація за місцем проживання, також використовуються злочинцями для перевезення через кордон нелегальних мігрантів або вивезення громадян до інших країн з послідуючим їх «продажем у якості живого товару».

Новим напрямком використання легальних каналів, в тому числі туристичних, є «експорт найманців» для участі у військових конфліктах. Тобто до країни на території якої налічується військовий конфлікт найманці можуть в'їхати легально під виглядом туриста. В сучасних умовах, це $\epsilon$ актуальним i для України.

I сприяють цим порушенням i злочинам не тільки корисні мотиви та намагання отримання неправомірні вимоги з боку чиновників, а й:

- окремі правові колізії чи взагалі правова неврегульованість вказаних процесів на законодавчому рівні; невідповідність окремих законодавчих та підзаконних актів, що регулюють відносини в туристичній галузі як вимогам вітчизняної міграційної політики, так і європейським чи світовим стандартам;

відсутність 3 боку держави дієвої системи координації та контролю процесів в туристичній галузі;

відсутність покарань та невідповідна системна профілактична робота в цьому напрямку відповідних органів та відомств;

відсутність координації дії законодавства про туризм і законодавства з протидії нелегальній міграції та торгівлі людьми;

недостатне спрямування наявних зусиль держави і суспільства на формування та реалізацію державної міграційної політики;

наявність

розширеної

пособницької бази нелегальної міграції на території України;

низький морально-етичний рівень посадових осіб, які протистоять нелегальній міграції;

- відсутність чітких та дієвих механізмів ефективної протидії нелегальній міграції та запобігання іiі негативних впливів.

Цей список не $€$ вичерпаним, виділені основні та найбільш актуальні на теперішній час причини.

Для виправлення ситуації, на нашу думку, необхідно запровадити наступні першочергові заходи, які доречі чітко прописані в Стратегії державної міграційної політики України на період до 2025 року, яка введена в дію Розпорядженням Кабінету Міністрів України від 12 липня 2017 р. № 482-року [11]:

участь України в системах 
PRADO (публічний реєстр документів, що посвідчують особу, та проїзних документів, розміщений на офіційному веб-сайті Ради Європейського Союзу) i FADO (он-лайн база даних справжніх i підроблених документів) шляхом надання інформації про зразки та особливості безпеки виданих в Україні документів, що посвідчують особу, підтверджують громадянство України чи спеціальний статус особи, та проїзних документів, а також шляхом надання доступу до українського веб-сайту недійсних документів;

запровадження процедури оперативного повідомлення про втрату документа, що посвідчує особу, підтверджує громадянство України чи спеціальний статус особи, власником документа для невідкладного внесення запису в реєстр;

забезпечення оперативного обміну інформацією про викрадені та втрачені документи, що посвідчують особу, підтверджують громадянство України чи спеціальний статус особи, між відповідними органами виконавчої влади України та ii передачі до баз даних Інтерполу 3 викрадених та втрачених паспортів;

- розроблення відповідних навчальних програм 3 підвищення кваліфікації для посадових осіб, які займаються видачею та обміном біометричних документів, 3 питань безпеки біометричних проїзних документів i виявлення фальсифікації первинних документів, долучення до цього процесу i співробітників туристичного сектору;

підвищення якості тренінгів для працівників консульських установ України 3 питань виявлення сфальсифікованих документів та потенційних нелегальних мігрантів; поліпшення взаємодії Державної міграційної служби 3 консульськими установами України щодо виявлення підроблених документів;
- налагодження мережі для проведення консультацій працівників консульських установ України та представників туроператорів 3 уповноваженими фахівцями відповідних органів державної влади на території України щодо безпеки документів та аналізу ризиків;

$$
\text { здійснення поступової }
$$
систематизації національного міграційного законодавства в рамках формування Міграційного кодексу України, яким будуть врегульовуватися всі питання міграції;

створення в рамках розвитку єдиної інформаційно-аналітичної системи управління міграційними процесами реєстру для автоматизованої обробки заяв, прийняття рішень про надання (відмову в наданні), продовження (відмову в продовженні) або скасування наданих посвідок на тимчасове та постійне проживання;

налагодження

системи

зв'язку для додаткових контактів у разі потреби 3 приватними / юридичними особами, які запрошують заявників;

регулярний перегляд та у разі потреби розширення або скорочення переліку необхідних документів для оформлення візи;

$\begin{array}{ccr}\text { - } & \text { сприяння } & \text { організованому } \\ \text { туризму } & \text { шляхом } & \text { вироблення }\end{array}$
консультативного механізму співпраці 3 урядовими і неурядовими установами та організаціями у зазначеній сфері;

$\begin{array}{ccr}\text { - } & \text { послідовне } & \text { впровадження } \\ \text { ефективної } & \text { методологіï } & \text { виявлення }\end{array}$ нелегальної міграції всередині держави, аналізу ризиків (звітування відповідних органів державної влади та аналіз на регіональному i центральному рівні), a також розслідування справ про організовану нелегальну міграцію.

Окремо слід зауважити, що першочерговими завданнями із зміцнення інституційних спроможностей для реалізації як запланованих дій, так і тих, що випливатимуть 3 нових потреб у сфері 
міграції, є:

посилення взаємодії органів державної влади та юридичних осіб публічного права у передбачених законом випадках, які здійснюють повноваження у сфері міграції;

$$
\text { створення }
$$

високопрофесійного потенціалу.

Посилення взаємодії органів державної влади у визначених законом випадках передбачає:

більш чітке визначення функцій, відповідальності та повноважень; вироблення ефективного, гнучкого та стійкого механізму міжвідомчого співробітництва;

посилення координуючої ролі Державної міграційної служби та Державної агенції з туризму та курортів.

Створення високопрофесійного кадрового потенціалу передбачає:

здійснення якісного добору

працівників, які претендують на зайняття посад, пов'язаних з виконанням функцій у сфері управління міграцією, за визначеними критеріями;

підвищення рівня знання іноземних мов працівниками державної міграційної служби;

організацію підготовки та підвищення кваліфікації державних службовців за напрямами, що передбачають професійну діяльність на державній службі у сфері міграції [11].

На нашу думку, дуже важливим i актуальним $\epsilon$ питання саме реалізації вищенаведеного, недопущення залишити розкриті заходи декларативними та нереалізованими. Необхідно розробити та ввести в дію як нормативно-правові акти, так i реальні, працюючі механізми їх реалізації. У зв'язку з цим удосконалення міграційної політики повинно бути одним із пріоритетів державної політики.

Висновки. На сучасному етапі розвитку України серед основних реальних та потенційних загроз державній безпеці слід визначити нелегальну міграцію, для здіснення якої в умовах інтенсифікації туризму активно використовуються туристичні канали.

Україна $\epsilon$ досить привабливою туристичною країною, а рівень туристичних потоків в сучасних умовах, незважаючи на економічні труднощі, зростає. Це позитивно відбивається на економічній складовій, $\epsilon$ важливим аргументом для підвищення іміджевого рівня держави, популяризації іiі у світі. В той же час, Україна відіграє і важливу роль у стримуванні потоків нелегальної міграції зі Сходу до держав Центральної та Західної Європи. Внаслідок того, що Україна одночасно $є$ державою походження, призначення та транзиту мігрантів, територією різнохарактерних, різноспрямованих та різномасштабних міграційних потоків, забезпечення державного регулювання у сфері міграції $\epsilon$ складним завданням, розв'язання якого потребує комплексного, системного підходу, належного фінансування, кадрового та наукового забезпечення.

\section{ПЕРЕЛІК ВИКОРИСТАНИХ ДЖЕРЕЛ}

1 Боков О.В. Міграційні процеси населення України в умовах іiі інтеграції до світового економічного простору/ О.В. Боков // Формування ринкових відносин в Україні: Збірник наукових праць. Вип. №10 (125), НДЕІ, Київ, 2012. - С. 200 206.

2 Василенко І.К. Протидія незаконній міграції населення $з$ країн Азії до Європи територією України (організаційно-правовий аспект): монографія / І. К. Василенко. - Донецьк: ВОНР ДЮІ ЛДУВС, 2008. - 172 с.
3 Коваленко
B.B.
Вплив організованої злочинності на стан міграції в Україні / В.В. Коваленко, В.І. Кривенко/ Проблеми боротьби 3 корупцією, організованою злочинністю та контрабандою. - К., 2001. - Т. 22. - С. $219-224$. 
4 Кресіна I. Нелегальна міграція: проблеми протидії та правового регулювання / I. Кресіна, О. Стойко // Політичний менеджмент. - 2009. - № 3(36). - C. 174-180.

5 Мозоль А.П. Кримінологічні проблеми нелегальної міграції в Україні: автореф. дис. на здобуття наук. ступеня кандидата юридичних наук / А.П. Мозоль. - Київ - 2002. - 189 с.

6 Левковський В.Ф. Нелегальна іграція - загроза національній безпеці України [Електронний ресурс] / В.Ф. Левковський. - Режим доступу: file:///C:/Users/User/Desktop/boz_2007_16_ 8\%20(1).pdf

7 Олефір В.І. Теоретикоконцептуальні засади міжнародноправового визначення нелегальної міграції / В.І. Олефір // Вісник ОІВС. - 2005. - № 1. - C. 158-164.
8 Нелегальна міграція та торгівля жінками (у 2 кн.). Кн.1 / За ред. Ю. Римаренка. - К. : ІДП. НАН, КУП, НABCУ, 2001.- 413 c.

9 Туристичні потоки [Електронний pecypc]. - Режим доступу: www.ukrstat.gov.ua

10 Про туризм: закон України від 15.09.1995 № 324/95-ВР [Електронний ресурс] // Відомості Верховної Ради України (ВВР), 1995,. N 31, ст. 241. Режим доступу: http://zakon3.rada. gov.ua/laws/show/324/95

11 Про схвалення Стратегії державної міграційної політики України на період до 2025 року : розпорядження від 12.07.17 р., № 482-р / Україна. Кабінет Міністрів // Урядовий кур'єр. - 2017. - № 140, 29 липня. - С. 11-12.

\title{
УДК 33:004
}

\section{РАЗВИТИЕ И БУДУЩЕЕ ЭКОНОМИКИ НА ОСНОВЕ ЦИФРОВЫХ ТЕХНОЛОГИЙ: КРИТИЧЕСКОЕ ОСМЫСЛЕНИЕ}

\author{
Компаниец В. В., д.э.н, профессор (УкрГУЖТ)
}

Приведены подходы к определению сущзности «ичифровой экономики». Доказано, что с точки зрения классического понимания экономики, речь долюна идти о иифровом секторе экономики. Критически осмыслены возможсности развития циифрового сектора экономики, последствия применения циффровых технологий в финансовой сфере и на основе этого возможности принципиального изменения модели экономики - перехода к посткапитализму.

Ключевые слова: цифровая экономика, цифровой сектор экономики, циффровые технологии, ІТ-сектор, производство, финансовый сектор, криптовалюта, цифровые деньги, управление, посткапитализм.

\section{РОЗВИТОК І МАЙБУТНЕ ЕКОНОМІКИ НА ОСНОВІ ЦИФРОВИХ ТЕХНОЛОГІЙ: КРИТИЧНЕ ОСМИСЛЕННЯ}

\author{
Компанієць В. В., д.е.н, професор (УкрДУЗТ)
}

Наведено підходи до визначення сутності «цифрової економіки». Доведено, щзо з точки зору класичного розуміння економіки, мова повинна йти про цифрровий сектор економіки. Критично осмислені можливості розвитку ицирового сектора економіки, 